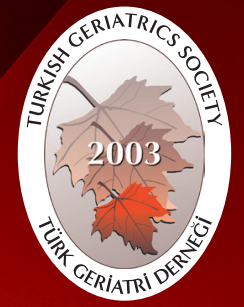

Turkish Journal of Geriatrics DOI: 10.31086/tigeri.2019.104 2019; 22(3): 287-294

- Çiçek KAPLAN ${ }^{1}$ iD

- Uğur BiLGE² (D)

- Nurdan $\operatorname{ACAR}^{3}$ iD

- IIlhami ÜNLÜOĞLU² D

CORRESPONDANCE

Çiçek KAPLAN

Yıldıztepe Family Healthcare Center, Family

Medicine, Eskişehir, Turkey.

Phone: +902222392979

Mobile: +905337137044

e-mail: tepebocuk84@hotmail.com

Received: 16/08/2017

Accepted: 11/07/2019

1Yıldıtepe Family Healthcare Center, Family Medicine, Eskişehir, Turkey.

Eskişehir Osmangazi University Faculty of Medicine, Family Medicine, Eskişehir, Turkey. Eskişehir Osmangazi University Faculty of Medicine, Emergency Department, Eskişehir, Turkey.
RESEARCH

\section{DETERMINATION OF POLYPHARMACY AND INAPPROPRIATE DRUG USE IN PATIENTS AGED OVER 65 YEARS WHO PRESENTED TO THE EMERGENCY DEPARTMENT}

\section{Abstract}

Introduction: No study in the literature has reported the rate of inappropriate drug use among older patients admitted to emergency department in Turkey. This study aimed to evaluate polypharmacy and inappropriate drug use by elderly patients admitted to the emergency department.

Materials and Method: Patients aged $\geq 65$ years were prospectively assessed for appropriateness of drugs they use between March and May 2016 according to both the 2012 Beers Criteria and STOPP Version 2 Criteria. Inappropriate drug use was separately assessed according to these criteria, and both patient and drug counts were calculated to assess inappropriate drug use in the study population. Age, gender, date of admission to the emergency department, blood pressure, pulse rate, respiratory rate, body temperature, oxygen saturation, state of consciousness, additional diseases, number of drugs used, names of drugs used, clinical outcome were recorded.

Results: Among 835 study participants, 406 (48.6\%) were females and 429 (51.4\%) were males. Mean age was $74.2 \pm 6.6$ years. The rate of polypharmacy and excessive polypharmacy was the highest in patients diagnosed with hypertension ( $35.0 \%$ and $16.0 \%$, respectively) and lowest in patients diagnosed with chronic renal failure (2.0\% and $2.0 \%$, respectively). In total, 835 patients were using 5637 drugs. Inappropriate drug use was present in 431 (51.6\%) patients according to the STOPP Version 2 Criteria and in 441 (52.8\%) according to the 2012 Beers Criteria.

Conclusion: Emphasis on inappropriate drug use will help physicians in the emergency department and other healthcare professionals reduce side effects and complications of medications and reduce emergency admissions to hospital.

Keywords: Inappropriate drug use; Potentially inappropriate medication list; Aged

ARAŞTIRMA

\section{ACIL SERVISE BAŞVURAN 65 YAŞ ÜZERi HASTALARDA POLIFARMASI VE UYGUNSUZ ILAÇ KULLANIMININ BELIRLENMESi \\ Öz}

Giriş: Türkiye'de acil servise başvuran yaşlı hastalarda literatürde herhangi bir uygunsuz ilaç kullanımı oranı bildirilmemiştir. Bu çalışma, acil servise başvuran yaşlı hastaların çoklu ilaç kullanımını ve uygun olmayan ilaç kullanımını değerlendirmeyi amaçlamıştır.

Gereç ve Yöntem: 65 yaşın üstündeki hastalar, 2012 Beers Kriterleri ve Yaşlı Kişilerin Potansiyel Olarak Uygun Olmayan Reçetelerinin Tarama Aracı Sürüm 2 Kriterlerine göre Mart ve Mayıs 2016 arasında kullandıkları ilaçların uygunluğu açısından prospektif olarak değerlendirildi. Uygun olmayan ilaç kullanımı bu kriterlere göre ayrı ayrı değerlendirildi ve hem hasta hem de ilaç sayıları, çalışma popülasyonunda $\mathrm{k}$ uygunsuz ilaç kullanımını değerlendirmek için hesaplandı.Yaş, cinsiyet, acil servise geliş tarihi, kan basıncı, nabız, solunum sayısı, vücut sıcaklığı, oksijen saturasyonu, bilinç durumu, ek hastalıklar, kullandığı ilaçlar ve isimleri ve klinik sonuçlanma kaydedildi.

Bulgular: 835 katılımcının 406'sı (\% 49) kadın, 429’’u (\% 51) erkekti. Yaş ortalaması $74.18 \pm 6.58$ yıldı Polifarmasi ve așııı polifarmasi oranı, hipertansiyon tanısı alan hastalarda (sırasıyla\% 35 ve \% 16) en yüksek, kronik böbrek yetmezliği tanısı alan hastalarda en düşüktü (sırasıyla\% 2 ve\% 2). Toplamda 835 hasta 5.637 ilaç kullanıyordu.Yaşlı Kişilerin Potansiyel Olarak Uygun Olmayan Reçetelerinin Tarama Aracı Versiyon 2 Kriterlerine göre 431 (\% 51.6) hastada uygunsuz ilaç kullanımı ve 2012 Beers kriterine göre 442 kișide (\% 52.9) uygunsuz ilaç kullanımı mevcuttu.

Sonuç: Uygunsuz ilaç kullanımına önem verilmesi, acil servisteki hekimlerin ve diğer sağlık çalıșanlarının ilaçların yan etkilerini ve komplikasyonlarını azaltmasına ve hastaneye acilen kabulü azaltmasına yardımc olacaktır.

Anahtar sözcükler: Uygunsuz ilaç kullanımı; Potansiyel uygunsuz reçete; Yaşııık 


\section{INTRODUCTION}

In recent years, the awareness of potential risks of inappropriate drug use has increased along with polypharmacy (multiple drug use) in the older population (age, >65 years). Polypharmacy is a risk factor that is likely to cause undesirable consequences, such as hospitalization and falls, as older people are more vulnerable to drug-drug interaction, side effects, and dosing errors (1).

Although defined and classified in different ways in different resources, polypharmacy generally refers to the use of 5-10 drugs by a patient. Use of $>10$ drugs is defined as excessive polypharmacy (2). In older individuals, polypharmacy is quite common given that they are diagnosed with multiple diseases. In this group, polypharmacy makes treatment more complicated and increases length of hospitalization and costs (3). Approximately $30.0 \%$ of hospitalization results from problems related to drug use (4). Furthermore, older patients are more susceptible to side effects of drugs and thus cannot use every drug. Studies mostly refer to the 2012 Beers Criteria for Potentially Inappropriate Medication Use in Older Adults to evaluate the appropriateness of medication (5). Prescribing appropriate medications to older patients reduces side effects (6). The aim of this study is to determine the rate of inappropriate drug use in older patients who were admitted to our emergency department and to make recommendations to reduce inappropriate drug use.

\section{MATERIALS AND METHOD}

After approval was obtained from the local Ethics Committee, this study was conducted in the Emergency Department of Eskisehir Osmangazi University Hospital between March and May 2016 based upon a prospective and observational research design. Patients aged $\geq 65$ years were included in the study. The exclusion criteria for participation in the study were age of $<65$ years and not providing informed consent for participation. The following information was noted on the observation form for each patient: age, gender, date of admission to the emergency department, blood pressure, pulse rate, respiratory rate, body temperature, oxygen saturation, state of consciousness, additional diseases, number of drugs used, names of drugs used, clinical outcome after the provision of medical care (discharge, hospitalization (in the intensive care unit or related medical department), refusal of treatment, transfer to another healthcare center, death, and leaving the hospital against medical advice).

Drugs Used and Appropriateness According to the 2012 Beers and STOPP Version 2 Criteria

For the purpose of this study, statistical analyses were performed based on the following parameters:

- The appropriateness of drugs according to the 2012 Beers and STOPP Version 2 Criteria

- The number of inappropriate drugs

- Falls caused by inappropriate drugs, according to the 2012 Beers Criteria

- The organ system affected by inappropriate drugs, according to the STOPP Version 2 Criteria

\section{Statistical Method}

IBM Corp. Released 2012. IBM SPSS Statistics for Windows, Version 21.0. Armonk, NY: IBM Corp. was used to perform statistical analyses. Categorical variables were presented as numbers (n) and percentages (\%). Continuous data are given as a mean \pm standard deviation.

\section{RESULTS}

The study was conducted with 835 patients: 406 (48.6\%) females and 429 (51.4\%) males. The participants' mean age was $74.2 \pm 6.5$ years. The distribution of comorbidities in the participants is presented in Figure 1. The relationship between 
comorbidities and number of drugs is provided in Table 1. Overall, 835 patients were using a total of 5,637 drugs. The average number of drugs used was $6.8 \pm 3.2$. The distribution of patients by the number of drugs used is presented in Table 2.

According to the STOPP Version 2 Criteria, the number of inappropriate drugs used was 688 in total and the number of patients using inappropriate drugs was 431 (51.6\%). The number of inappropriate drugs used was one drug in 241 (28.9\%) patients, two in 137 (16.4\%), three in 41 $(4.9 \%)$, four in $10(1.2 \%)$, and five in two $(0.2 \%)$ (Table 3). According to the 2012 Beers Criteria, the number of inappropriate drugs used by participants was 843 and the number of patients using inappropriate drugs was 442 (52.9\%). The number of inappropriate drugs was one drug in 205 (24.6\%) patients, two in 133 (15.9\%), three in 58
(6.9\%), four in $33(4.0 \%)$, five in $12(1.4 \%)$, and six in one $(0.1 \%)$ (Table 3$)$.

\section{Profiles of Inappropriate Drugs}

According to the 2012 Beers Criteria, the most commonly used inappropriate drugs are SSRIs (122 patients, 14.6\%), strong anticholinergics (97, $11.6 \%)$, NSAIDs (86, 10.3\%), and aspirin (58, 6.9\%). According to the STOPP Version 2 Criteria, the most common violations were related to the category of duplication (165 patients, 19.8\%), cardiovascular system $(107,12.8 \%)$, use of antiplatelet drugs (103, $12.3 \%)$, and central nervous system (87, 10.4\%). According to the STOPP Version 2 Criteria, the most frequently duplicated drugs were NSAIDs (66 patients, $40.0 \%)$, steroids for respiratory disorders (23, 14.0\%), proton-pump inhibitors $(18,11.0 \%)$, thiazide diuretics $(18,11.0 \%)$, ASA $(13,8.0 \%)$, and paracetamol $(13,8.0 \%)$.

Table 3. Univariate and multivariate analyses for predictors of frequent premature ventricular contraction

\begin{tabular}{|c|c|c|c|c|c|c|}
\hline \multirow{2}{*}{\multicolumn{2}{|c|}{ Comorbidities }} & \multicolumn{4}{|c|}{ Number of drugs } & \multirow{3}{*}{$\begin{array}{l}\text { Total } \\
610(73.0 \%)\end{array}$} \\
\hline & & \multirow{2}{*}{$\begin{array}{r}0 \\
14(2.0 \%)\end{array}$} & \multirow{2}{*}{$\begin{array}{r}\mathbf{1 - 5} \\
255(31.0 \%) \\
\end{array}$} & \multirow{2}{*}{$\begin{array}{r}\text { 6-9 } \\
262(31.0 \%)\end{array}$} & \multirow{2}{*}{$\begin{array}{r}>9 \\
79(9.0 \%)\end{array}$} & \\
\hline & No & & & & & \\
\hline & Yes & $1(0.1 \%)$ & $46(6.0 \%)$ & 107 (13.0\%) & 71 (9.0\%) & 225 (27.0\%) \\
\hline \multirow{2}{*}{ HT } & No & $14(2.0 \%)$ & 149 (18.0\%) & 78 (9.0\%) & $13(2.0 \%)$ & 254 (39.0\%) \\
\hline & Yes & $1(0.1 \%)$ & $152(18.0 \%)$ & 291 (35.0\%) & $137(16.0 \%)$ & $581(70.0 \%)$ \\
\hline \multirow{2}{*}{ COPD } & No & 15 (2.0\%) & 276 (33.0\%) & 276 (33.0\%) & 91 (11.0\%) & $658(79.0 \%)$ \\
\hline & Yes & $0(0.1 \%)$ & 25 (3.0\%) & 93 (11.0\%) & 59 (7.0\%) & 177 (21.0\%) \\
\hline \multirow{2}{*}{ CRF } & No & 15 (2.0\%) & 289 (35.0\%) & 350 (42.0\%) & $133(16.0 \%)$ & 787 (94.0\%) \\
\hline & Yes & $0(0.1 \%)$ & $12(1.0 \%)$ & $19(2.0 \%)$ & 17 (2.0\%) & 48 (6.0\%) \\
\hline \multirow{2}{*}{$\mathrm{CHF}$} & No & 15 (2.0\%) & 294 (35.0\%) & 325 (39.0\%) & 98 (12.0\%) & $732(88.0 \%)$ \\
\hline & Yes & $0(0.1 \%)$ & 7 (1.0\%) & 44 (5.0\%) & 52 (6.0\%) & 103 (12.0\%) \\
\hline \multirow{2}{*}{ CAD } & No & 15 (2.0\%) & 251 (30.0\%) & $183(22.0 \%)$ & 37 (4.0\%) & 486 (58.0\%) \\
\hline & & 0 (0.1\%) & 50 (6.0\%) & 186 (22.0\%) & $113(14.0 \%)$ & 349 (42.0\%) \\
\hline \multirow{2}{*}{ Others } & No & 15 (2.0\%) & 70 (8.0\%) & 37 (4.0\%) & $11(1.0 \%)$ & $133(16.0 \%)$ \\
\hline & Yes & $0(0.1 \%)$ & $231(28.0 \%)$ & $332(40.0 \%)$ & $139(17.0 \%)$ & $702(84.0 \%)$ \\
\hline
\end{tabular}

DM, diabetes Mellitus; $H T$, hypertension; COPD, chronic obstructive pulmonary disease; CRF, chronic renal failure; CHF, congestive heart failure; CAD, coronary artery disease 
The use of anticholinergics in patients admitted to the emergency department after a fall was investigated, and seven of 35 patients were found to be inappropriately using anticholinergics according to the 2012 Beers Criteria and five were inappropriately using anticholinergics according to the STOPP Version 2 Criteria.

Table 2. Distribution of the number of drugs among patient.

\begin{tabular}{|c|r|r|}
\hline Number & $\begin{array}{r}\text { Number of } \\
\text { patients }\end{array}$ & Percentage (\%) \\
\hline 0 & 15 & 1.8 \\
\hline $1-5$ & 301 & 36.0 \\
\hline $6-9$ & 369 & 44.2 \\
\hline$>9$ & 150 & 18.0 \\
\hline Total & 835 & 100.0 \\
\hline
\end{tabular}

\section{DISCUSSION}

The participants' mean age was $74.2 \pm 6.6$ years. Given that life expectancy is 79.4 years in females and 73.7 years in males according to 2015 data, the older population provides an important source of information in Turkey.

The population census of Turkey in 2015 showed that the number of people aged $\geq 65$ years was 6495239 (8.2\% of the total population). There is limited information in the literature particularly with regard to the elderly. Because of the aging of the population in Turkey and lack of sufficient information in the literature, this study potentially provides a significant source of information for the treatment of older individuals.

This study has focused on inappropriate drug use in the elderly based on the STOPP Version 2 Criteria and 2012 Beers Criteria. Given that the number of similar studies is limited in the literature, the present study may play a guiding role in research.

Increase in the aging population has affected the entire healthcare system, particularly the

Table 3. Univariate and multivariate analyses for predictors of frequent premature ventricular contraction.

\begin{tabular}{|c|c|c|c|c|}
\hline \multirow{2}{*}{$\begin{array}{l}\text { Number of } \\
\text { Inappropriate } \\
\text { drug use }\end{array}$} & \multicolumn{2}{|c|}{2012 Beers Criteria } & \multicolumn{2}{|c|}{ STOPP Version 2 Criteria } \\
\hline & $\begin{array}{r}\text { Number of } \\
\text { patients }\end{array}$ & $\%$ & $\begin{array}{r}\text { Number of } \\
\text { patients }\end{array}$ & $\%$ \\
\hline 0 & 393 & 47.1 & 404 & 48.4 \\
\hline 1 & 205 & 24.6 & 241 & 28.9 \\
\hline 2 & 133 & 15.9 & 137 & 16.4 \\
\hline 3 & 58 & 6.9 & 41 & 4.9 \\
\hline 4 & 33 & 4.0 & 10 & 1.2 \\
\hline 5 & 12 & 1.4 & 2 & 0.2 \\
\hline 6 & 1 & 0.1 & 0 & 0.0 \\
\hline Total & 835 & 100.0 & 835 & 100.0 \\
\hline
\end{tabular}


emergency medicine services. In 2002, 58.0\% of the population aged $\geq 75$ years presented to emergency departments at least once in the United States. This rate corresponds to $39.0 \%$ of the total population (7).

This information suggests that the workload in emergency departments everywhere is expected to increase with the increase in the older population. The present study yields important data about polypharmacy and inappropriate drug use in elderly patients admitted to the emergency department.

In terms of comorbidities, Ünsal et al. reported in 2003 that patients aged $\geq 65$ years presented most commonly to the emergency department because of hypertension (HT) and cardiovascular diseases (8). In the present study, the comorbidities were, in descending order of frequency, HT (69.5\%), coronary artery disease (CAD) (41.8\%), diabetes mellitus (DM) (26.9\%), chronic obstructive pulmonary disease (COPD) (21.2\%), and congestive heart failure (CHF) (12.3\%). In this study, diseases such as HT, CAD, DM, COPD, and CHF were more frequently encountered probably because the data were collected from the emergency department.

The increase in the number of chronic diseases is considered to be one of the most important risk factors for polypharmacy. In the present study, we found that $44.2 \%$ of the patients were using six or more drugs and $18.0 \%$ of the patients were using 10 or more drugs. In this study, the average number of drugs was $6.6 \pm 3.2$. Kaufman et al. conducted a study in the United States in 2002, wherein they reported polypharmacy in $57.0 \%$ of females and $44.0 \%$ of males aged $\geq 65$ years. In the same study, they found that $12.0 \%$ of females and males were using 10 or more drugs (9).

In this study, the prevalence of inappropriate drug use was $51.6 \%$ according to the STOPP Version 2 Criteria and $52.9 \%$ according to the 2012 Beers Criteria. The worldwide prevalence of inappropriate drug use was reported to be $13.0 \%-$ 35.0\% according to the STOPP Version 2 and 2012 Beers Criteria (10). In a 2012 study by Blanco-Reina et al., the prevalence of inappropriate drug use was 24.3\% according to 2003 Beers, 35.4\% according to STOPP Version 1, and $44.0 \%$ according to 2012 Beers Criteria in 407 elderly patients admitted to primary healthcare centers (11). In a 2014 study by Jhaveri et al., the rate of inappropriate drug use was quite high according to the 2012 Beers Criteria (87.3\%) in 676 elderly patients (average age, 72.7 years) who were hospitalized in tertiary healthcare centers (12). Davidoff et al. investigated the prevalence of inappropriate drug use in the United States in 2015 in 18475 elderly patients and reported that the rate was $40.8 \%$ between 2006 and 2010 according to the 2012 Beers Criteria. In the United States, the most common inappropriately used drug was NSAID (10.9\%) according to the 2012 Beers Criteria (13).

In a study by Lam et al. in 2015 with elderly patients treated and hospitalized in a tertiary healthcare center, it was reported that the rate of inappropriate drug use was $31.6 \%$ and $38.6 \%$ according to the STOPP Version 1 and 2012 Beers Criteria, respectively (14).

This study showed that NSAIDs are one of the most common inappropriately used drug classes. The use of NSAIDs is associated with increased gastrointestinal and cardiovascular risks, particularly in older patients. NSAIDS are also more likely to cause problems in renal function in older patients. Furthermore, a recent study found that NSAIDs constitute an independent risk factor for community-acquired hyperkalemia (15).

It is known that the inappropriate use of NSAIDs may cause gastric irritation, chronic blood loss, anemia, sodium retention, and kidney failure, particularly in patients aged >65 years. Druginduced nephrotoxicity is likely to reduce the effectiveness of antihypertensive drugs. The use of NSAIDs is associated with a two-fold increased risk of chronic kidney disease, especially in patients aged $>65$ years. Furthermore, inappropriate use of NSAIDs is reported in patients with kidney failure $(16,17,18)$. 
Figure 1. Comorbidities of the patients.

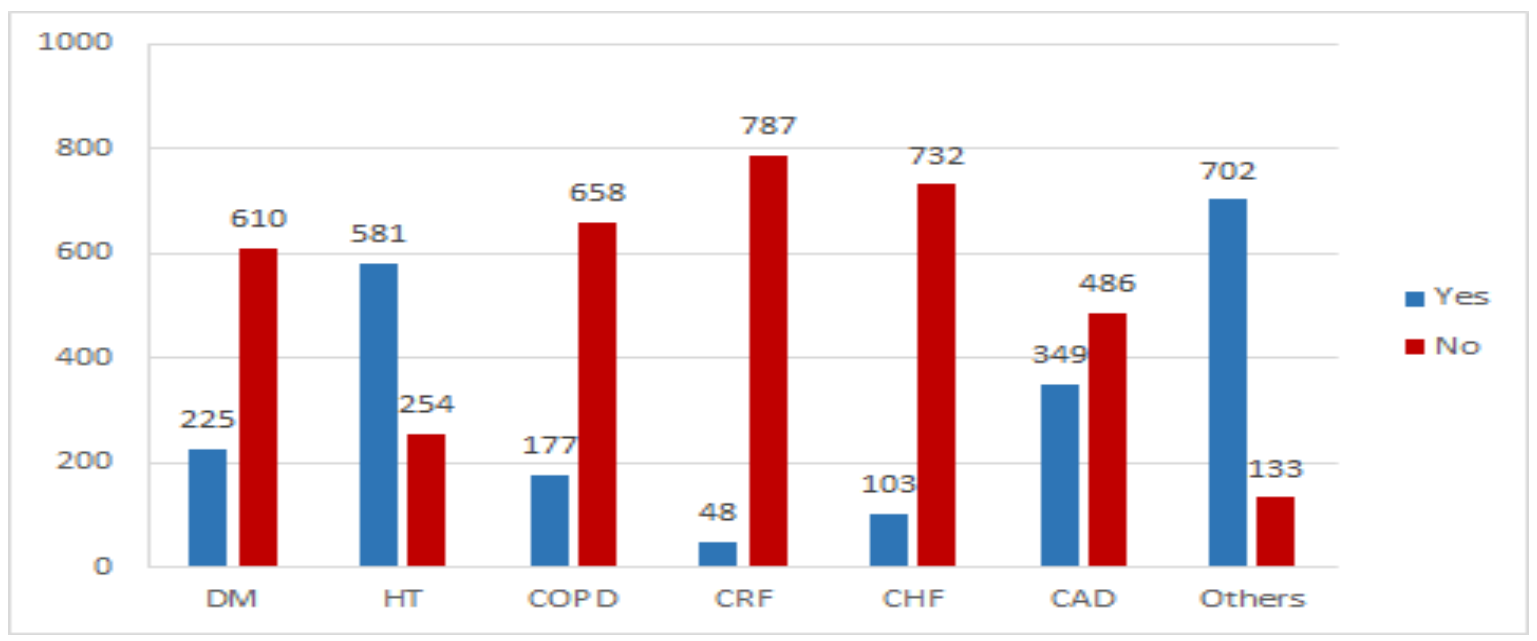

DM, diabetes Mellitus; $H T$, hypertension; COPD, chronic obstructive pulmonary disease; CRF, chronic renal failure; CHF, congestive heart failure; CAD, coronary artery disease.

In the present study, 35 patients presented to the emergency department after a fall. According to the STOPP Version 2 Criteria, $20.0 \%$ of these patients were taking drugs with apparent anticholinergic activity. It is known that inappropriate drug use increases the risk of falls in older patients. This is mostly associated with anticholinergic medications, as well as longterm use of benzodiazepines and psychotropic medications. Primary healthcare providers must pay special attention when prescribing medications with anticholinergic effects (e.g., tricyclic antidepressants and antihistamines) to elderly patients $(19,20)$.

An emphasis on inappropriate drug use will help physicians in the emergency department and other healthcare professionals reduce side effects and complications of medications and potentially reduce emergency admissions to hospitals. Thus, healthcare providers should pay more attention to inappropriate drug use, drugdrug interactions, and possible side effects of drugs, particularly in patients aged $>65$ years. It should also be emphasized that the 2012 Beers and STOPP Version 2 Criteria are developed not to replace physicians' decisions but to guide them to appropriately prescribe medications.

This study has some limitations. This study was conducted in the emergency department. Therefore, no detailed information about patients, such as glomerular filtration rate or systolic ejection fraction, was available. Because there was no information regarding where patients lived, no comparison was made between patients living in their home and those living in geriatric care centers. This study was conducted in only one healthcare center.

In conclusion, inappropriate drug use is a major healthcare problem across the world. The 2012 Beers and STOPP Version 2 Criteria used in this study are not intended to replace clinical assessment but rather to facilitate and support clinical processes. Therefore, these criteria cannot be the only sources of information that guide medication choice. The aim of these criteria is to protect patients from the side effects of drugs and improve the quality of treatment while prescribing a minimum number of drugs. Based on the 
findings of the present study, the 2012 Beers and STOPP Version 2 Criteria are recommended as a resource for prescribing drugs for elderly patients with the added benefit of improving the quality of healthcare services. The present study and previous worldwide studies suggest that these criteria are effective methods for determining inappropriate drug use.

To the best of our knowledge, the present study is the first investigation on the use of the

\section{REFERENCES}

1. Jyrkkä J, Enlund $H$, Korhonen MJ, Sulkava $R$, Hartikainen S. Polypharmacy status as an indicator of mortality in an elderly population. Drugs Aging 2009;26(12):1039-48. (PMID:19929031)

2. Walckiers D, Van der Heyden J, Tafforeau J. Factors associated with excessive polypharmacy in older people. Arch Public Health 2015;73(1):1-12. (PMID:26557365)

3. Kutsal YG. Polypharmacy in elderly. Tur J Geriatrics 2006;9:37-44.

4. American Geriatrics Society 2012 Beers Criteria Update Expert Panel. American Geriatrics Society updated Beers Criteria for potentially inappropriate medication use in older adults. J Am Geriatr Soc 2012;60(4):616-31. (PMID:22376048)

5. Gallagher P, Barry P, O'Mahony D. Inappropriate prescribing in the elderly. J Clin Pharm Ther 2007;32(2):113-21. (PMID:17381661)

6. Wallace J, Paauw DS. Appropriate prescribing and important drug interactions in older adults. Med Clin North Am 2015;99(2):295-310. (PMID:25700585)

7. Pines JM, Mullins PM, Cooper JK, Feng LB, Roth KE. National trends in emergency department use, care patterns, and quality of care of older adults in the United States. J Am Geriatr Soc 2013;61(1):12-7. (PMID: 23311549)

8. Unsal A, Çevik AA, Metintaş S, Arslantaş D, Inan OC. Emergency department visits by elder patients. Tur J Geriatrics 2003;6:83-8.

9. Kaufman DW, Kelly JP, Rosenberg L, Anderson TE, Mitchell AA. Recent patterns of medication use in the ambulatory adult population of the United States: The Slone survey. JAMA 2002;287(3):337-44. (PMID:11790213)
STOPP Version 2 and 2012 Beers Criteria to analyze polypharmacy and inappropriate drug use among elderly patients admitted to an emergency department and is considered to play a guiding role to healthcare services for the elderly in Turkey and around the world.

\section{CONFLICT OF INTEREST}

The authors declare no conflict of interest.

10. Chen LL, Tangiisuran B, Shafie AA, Hassali MA. Evaluation of potentially inappropriate medications among older residents of Malaysian nursing homes. Int J Clin Pharm 2012;34(4):596-603. (PMID: 22622593)

11. Blanco-Reina E, Ariza-Zafra G, Ocana-Riola R, Leon-Ortiz M. 2012 American Geriatrics Society Beers criteria: enhanced applicability for detecting potentially inappropriate medications in European older adults? A comparison with the Screening Tool of Older Person's Potentially Inappropriate Prescriptions. J Am Geriatr Soc 2014;62(7):1217-23. (PMID:24917083)

12. Jhaveri BN, Patel TK, Barvaliya MJ, Tripathi C. Utilization of potentially inappropriate medications in elderly patients in a tertiary care teaching hospital in India. Perspect Clin Res 2014;5(4):184-9. (PMID:25276629)

13. Davidoff AJ, Miller GE, Sarpong EM, Yang E, Brandt N, Fick DM. Prevalence of potentially inappropriate medication use in older adults using the 2012 Beers criteria. J Am Geriatr Soc 2015;63(3):486-500. (PMID:25752646)

14. Lam MP, Cheung BM, Wong IC. Prevalence of potentially inappropriate prescribing among Hong Kong Older adults: a comparison of the Beers 2003, Beers 2012, and screening tool of older person's prescriptions and screening tool to alert doctors to right treatment criteria. J Am Geriatr Soc 2015;63(7):1471-2. (PMID:26189852)

15. Turgutalp K, Bardak, S, Helvacı I, et al. Communityacquired hyperkalemia in elderly patients: risk factors and clinical outcomes. Ren Fail 2016;38(9):1405-12. (PMID:27494301)

16. Willams CM. Using medications appropriately in older adults. Am Fam Physician 2002;66(10):1917-24. (PMID:12469968) 
17. Sandler DP, Burr FR, Weinberg CR. Nonsteroidal anti-inflammatory drugs and the risk for chronic renal disease. Ann Intern Med 1991;115(3):165-72. (PMID:2058870)

18. Bilge U, Sahin G, Unluoglu I, Ipek M, Durdu M, Keskin A. Inappropriate use of nonsteroidal antiinflammatory drugs and other drugs in chronic kidney disease patients without renal replacement therapy. Ren Fail 2013;35(6):906-10. (PMID:23725334)
19. Berdot S, Bertrand M, Dartigues JF, et al. Inappropriate medication use and risk of falls-a prospective study in a large community-dwelling elderly cohort. BMC Geriatr 2009;9:30. [Internet] Available from: https://doi.org/10.1186/1471-2318-9-30. Accessed: 10.06.2019. (PMID:19627577)

20. Blix HS, Viktil KK, Moger TA, Reikvam A. Use of renal risk drugs in hospitalized patients with impaired renal function: an underestimated problem? Nephrol Dial Transplant 2006;21(11):3164-71. (PMID:16880181) 